\title{
The Networking Behaviour of Immigrant Entrepreneurs in South Africa
}

\section{Olawale Fatoki}

\author{
Department of Business Management, Turfloop campus, University of \\ Limpopo, Limpopo Province, South Africa \\ Email: Olawale.fatoki@ul.ac.za \\ Olabanji Oni \\ Department of Business Management, Turfloop campus, University of \\ impopo, Limpopo Province, South Africa \\ Email: Olabanji.oni@ul.ac.za
}

Doi:10.5901/mjss.2014.v5n20p284

Abstract

This study investigated the networking behavior of immigrant entrepreneurs during two different phases of business (start-up and established). Networking was divided into three types: social, official and business. The survey was qualitative in nature. Data was collected through the use of in-depth interviews from twenty nine immigrant entrepreneurs. The results indicated that social networks which can be categorised as strong ties are dominant during the start-up phase of business. Business networks which can be categorised as weak ties are dominant during the established stage of the business. However, social network also helps to provide resources during the established phase as most entrepreneurs at this stage use family members and co-ethnics as employees. The use of official networks is weak in both the start-up and established phases. Recommendations to improve networking by immigrant entrepreneurs are suggested.

Keywords: immigrant entrepreneurs, social, business, general, networking, South Africa

\section{Introduction}

Aguilar (2013) points out that immigrant entrepreneurs make significant contributions to the economy of a country. Immigrant entrepreneurs are business owners and create jobs. Immigrant entrepreneurs increase a nation's capacity to develop new ideas and contribute to competitiveness in the business landscape. Kalitanyi and Visser (2010) find that find that more than 80 per cent of African immigrant entrepreneurs employ South Africans in their businesses. In addition, entrepreneurial skills are transferred from immigrant entrepreneurs to their South African employees. Thus, immigrant entrepreneurs contribute to the growth and development of South Africa. Tengeh et al. (2012) remark that by creating employment, immigrant entrepreneurship is one of the solutions to poverty and income inequality in South Africa.

Fairlie and Lofstrom (2013) assert that immigrant entrepreneurs face some barriers in starting and growing their business. Access to resources is one of the major obstacles faced by immigrant entrepreneurs. According to Tesfom (2006) and Foss (2010), access to resources is a key challenge facing entrepreneurs especially during early venture development. Entrepreneurs need information, capital, skills, and labour to start business activities. Entrepreneurs hold some of these resources themselves but often have to complement their resources by accessing their contacts. Entrepreneurs' networks serve as a principal means of identifying and acquiring needed resources. The personal network of the entrepreneur is one of the most significant resources of the firm. Effective entrepreneurs are able to view networking as a crucial aspect of ensuring success of their company. Network ties are useful in mitigating the problem of information asymmetry faced by entrepreneurs when acquiring resources at the early stage of venture creation.

Machirori and Fatoki (2013) point out that entrepreneurial networking includes official, business (managerial) and social networking. Official networks consist of government and government agencies. Social networks include friends, family and relatives and business networks comprise of competitors, suppliers, banks and customers, chambers of commerce and accountants. El Bouk et al. (2013) remark that different stages of venture development may need different resource dependencies. Resource requirements during the start-up phase of a business may be different from the established or growth phase. Sullivan (2006) observes that the nature of networks is dynamic, due different resource requirements over time. This suggests that entrepreneurs' networks may need to change to meet shifting resource 
requirements. Immigrant entrepreneurs may require different networks and resources at different phases of their business. The study builds upon an extensive scholarship on networking and entrepreneurship. The study will help to enhance the understanding of how the networking activities of immigrant entrepreneurs change over time.

\section{Objective of the Study}

Immigrant entrepreneurs need networking in order to obtain resources at start-up and established phases of their business. The objective of the study is to investigate the networking activities of immigrant entrepreneurs during different phases of their business. The study will examine the types of networking that provide the relevant resources in the critical start-up phase and how networking changes when the business reaches the established stage. The study identifies three types of networking. These are social, general and business networks.

\section{Research Questions}

(1) What kind of networking provides resources to immigrant entrepreneurs during the start-up phase?

(2) What kind of networking provides resources to immigrant entrepreneurs during the established phase?

\section{Literature Review}

\subsection{Entrepreneurship and immigrant entrepreneurship}

There is no single universally acceptable definition of the term entrepreneurship. Various definitions have emerged in an attempt to explain entrepreneurship. Gedeon (2010) points out that the term entrepreneurship (or who is an entrepreneur) lacks a single unified and accepted definition. The literature is replete with criteria ranging from creativity and innovation to personal traits such as appearance and style (Fernald et al. 2005). According to Gedeon (2010), Cantillon, Turgot, Say and Schumpeter laid the foundations for the meaning of entrepreneurship. Cantillon defines the entrepreneur as someone who assumes the risk and may legitimately appropriate any profits. Turgot and Say point out that the entrepreneur obtains and organizes production factors to create value. Schumpeter (1934) relates entrepreneurship to innovation. The innovative activity of entrepreneurs feeds a creative "destruction process" by causing constant disturbances to an economic system in equilibrium, creating opportunities for economic rent. In adjusting to equilibrium, other innovations are spun-off and more entrepreneurs enter the economic system. McCleland (1961) asserts that entrepreneurial activity involves risk-taking, energetic activity, individual responsibility, money as a measure of results, anticipation of future possibilities, and organizational skills. Drucker (1985) notes that the entrepreneur always searches for change, responds to it, and exploits it as an opportunity. Innovation is the tool of entrepreneurship

The link between immigration and entrepreneurship is supported by a number of studies (Dana 2007). Immigrant entrepreneurship is described as the process by which an immigrant establishes a business in a host country (or country of settlement) which is not the immigrant's country of origin (Dalhammar 2004). According to Aaltonen and Akola (2014), an immigrant entrepreneur is a person who has immigrated to a new country and started a business there. Vinogradov (2008) describes an immigrant entrepreneur as a person who arrives in the country and starts a business for the purpose of economic survival Aaltonen and Akola (2014) point out that immigrant business owner is used as a synonym for an immigrant entrepreneur. The definition of an immigrant entrepreneur includes those individuals who employ themselves as well as those who employ also others.

\subsection{Organisational Life Cycle}

Griener (1972) provides one of the earliest theoretical foundations for a firm's life cycle. Griener identifies five phases for the organisation: Creativity, direction, delegation, coordination and collaboration. Adizes (1979) categorises ten life cycle stages for a firm: courtship, infancy, go-go, adolescence, prime, stability, aristocracy, recrimination, bureaucracy and death. Churchill and Lewis (1983) analyse five stages of small enterprise growth: start-up stage, survival stage, successful stage, take-off stage and mature stage. A venture is considered new if it has not yet reached a phase in its development where it could be considered a mature business. The precise moment in time in which a new venture becomes a mature business has not yet been determined. However, the idea of business maturation could be equated with a firm that has fully completed the transition out of the earliest stages of the life cycle (Grunhagen and Mittelstaedt 2002). In South Africa, according to Maas and Herrington (2006) a new business is one that has existed for less than 
forty two months. After that period, the business is considered established. Islam (2009) points out that a business needs resources at the start-up or growth phase. Shortage of fixed and working capital are the common factors that inhibit the entrepreneurs to start and run their business smoothly.

\subsection{Resource need of a firm and networking}

Pfeffer and Salanick (1978) introduced the Resources Dependency Theory (RDT). The theory focuses on how the external resources of organizations affect the behaviour of the organization. According to the RDT, successful performance of a firm depends on resources and supporting networks. The resources and supports are, particularly important for small firms who have to depend on some external actors. Firms are linked to their environments by federations, associations, customer-supplier relationships, competitive relationships, and a social-legal apparatus that define and control the nature and limits of these relationships as well. Watson (2007) points out that networking involves information and resources sharing, reduction of costs and social interactions that exist between individuals and organisations. Research conducted by Zhang and Fung (2006) finds a positive relationship between networking and firm performance. Chen et al. (2007) provide evidence that firms with individuals that accumulate their social capital gain benefits as it promotes their business size, market share and performance. Thrikawala (2011) points out that linkage with government improve firm performance by providing resources and information. Eisingerich and Bell (2008) conclude that the capacity of a firm to manage the balance between strong and open network linkages is a key source of sustainable firm performance. Ngoc et al. (2009) and Chen and He (2011) point out that networking play an important role in spreading knowledge about a firm's existence and its practices. Networking also help a firm learn appropriate behaviour and increases a firm's legitimacy. Thus, networking positively influences the firm's access to external resources.

There is no universally accepted way to classify entrepreneurial networks. Ngoc et al. (2009) categorised networks into three main types: (1) official networks - or networks with government officials; (2) managerial networks - networks with suppliers, customers and business associations and (3) social networks - networks with relatives and friends and networks with members of social organizations and clubs.. Stephens (2013) focuses only on business networks. The members of a business network include local government representatives, members of local development bodies, accountants, business consultants, academics, bank managers, members of the local chamber of commerce, family members and other small business owners. Machirori and Fatoki (2013) point out that networking includes official, business (managerial) and social networking.

Chen and He (2011) and El Bouk et al. (2013) describe social networks as a web of persons who interact with each other on a regular basis. Social networks consist of strong ties and weak ties. The strength of the tie determines which type of resources can be exchanged and under what conditions. Strong ties consist of high-trust relations between people who are willing to exchange resources out of feelings of solidarity. Family and friends are characterised as strong ties. These are persons with whom the entrepreneurs shared a close emotional relationship. Weak ties are characterised as low-trust relations. Weak ties do not have the intimacy or the emotionality of strong ties. Business relations, formal employees, financial support from suppliers and commercial banks are characterised as weak ties. This suggests that business and official networking discussed above can be categorised as weak ties and social networking of family and friends can be categorised as strong ties.

\section{Research Methodology}

The survey was conducted in the Johannesburg Central Business District in Gauteng province of South Africa. The area is suitable for research because of the high number of immigrant entrepreneurs. Because of the difficulty of obtaining the population of immigrant-owned businesses in the study area, purpose sampling and the snowball sampling methods were used. The study focused on immigrant entrepreneurs that are business owners in the retail sector. The study used the qualitative research technique. According to Bricki and Green (2007), qualitative research is characterised by its aims, which relate to understanding some aspect of social life, and its methods which generate words, rather than numbers, as data for analysis. In-depth interview method was used for data collection. Guion et al. (2011) point out that in-depth interviews are a qualitative data collection technique that can be used for a variety of purposes. In-depth interviews are very suitable for situations in which the researcher wants to use open-ended questions to obtain information in depth from relatively few people. Interviews were conducted with the participants and recorded. Each interview took about one hour and was done at the convenience of the participant. Opening questions focused on the biographical details of focused on the participants. The participants were then asked questions about their networking. The participants were encouraged to expand their answers through additional probing questions. The interviews were recorded. The summary of some of the 
interviews is presented in the results and discussions section. This study splits networking into three types. These are official, business (managerial) and social networking. Official networks consist of government and government agencies. Social networks include friends, family and relatives and business networks comprise of competitors, suppliers, banks and customers, chambers of commerce and accountants.

\section{Results and Discussions}

Twenty nine immigrant entrepreneurs agreed to participate in the survey. Seven respondents can be considered as new entrepreneurs (i.e. the business is not older than 42 months) and twenty two can be considered as established entrepreneurs (the business is older than 42 months). All the respondents are in the retail sector. Out of the seven respondents that are new entrepreneurs, four have previous entrepreneurial experience having worked in the same sector with other immigrant entrepreneurs and three respondents have no previous entrepreneurial experience. Six respondents are female and twenty three respondents are male.

\subsection{Networking behaviour during the start-up phase}

Out of the seven respondents that are new entrepreneurs, four have previous entrepreneurial experience having worked in the same sector with other immigrant entrepreneurs and three respondents have no previous entrepreneurial experience. The entrepreneurs were asked how they obtained the resources that they used in the start-up phase. Resources include information, capital, skills, and labour to start business activities.

The results indicate that for immigrant entrepreneurs who have new businesses but without previous entrepreneurial experience (have not worked for another entrepreneur), all the four respondents depended on financial resources from themselves, family and friends. Some of the family and friends are also business owners. Information about the business and potential profitability was also obtained from family, friends and other co-ethnics. In addition, one of the respondents was assisted by his wife and another by his brother at start-up as they could not employ paid assistants because of cost. All the three immigrant entrepreneurs without previous entrepreneurial experience depended on social networks that can be categorised as strong ties. None of the respondents was able to obtain resources from suppliers and commercial banks (business network) and none of them was able to obtain resources from any government agency that support small businesses (official networks). For the four respondents with previous entrepreneurial experience, three obtained the necessary resources from their own contribution, and family, friends and other ethnic entrepreneurs (social networks with strong ties) and only one obtained resources from suppliers. This implies that business networks established during previous entrepreneurial activities can also help to obtain resources.

Participant: "I have some friends who are already in the line of business that I was interested in. They provided information about the business opportunity, the capital required and the profitability of the business. They also helped me out financially by adding to my capital and giving me some goods on credit. We did not sign any formal agreement. The suppliers were not willing to sell to me on credit probably because I was new. I also could not approach the bank for credit because I did not start with any business plan. I also have no collateral. I did not have any employee. I was not aware of any government agency that can help with the financing of my business and so did not approach them. Also, I could not afford an accountant or a paid business consultant. There was no way that I could have started this business without friends and other people from my country that I was later introduced to."

Participant: "I worked for a business man from my country for four years before I decided to start my own business in the same line. I had all the information about the business and knew our suppliers. I also saved some money. When I started, I obtained some help from my wife who also contributed financially to my business. Also I was able to get goods on credit from my former boss and some traders from my country. My boss also linked me up with one of the suppliers who agreed to sell wares to me on credit. My wife also helps with the business although I cannot really call her an employee. I had a bank account but I did not approach the bank for credit because I felt I would be rejected as only my salary was paid into the account and it was not much. I did not approach any government agency for assistance although I have information about some of them that provide financial and non-financial assistance."

The results show that during the start-up stage, immigrant entrepreneurs depend mostly on social networks especially strong ties from family and friends and other co-ethnics who are already business owners. These networks provide information about the business, help with financial contribution and link with suppliers. The use of business and official networks which can be categorised as weak ties is limited. 


\title{
6.2 Networking behaviour during the established phase
}

Twenty two respondents that can be considered as established entrepreneurs. All of them agree that their business has grown since inception. In addition, sixteen respondents have established relationships with suppliers, fourteen respondents have an overdraft or a loan and nineteen respondents make use of credit card. Five respondents use accountants for book keeping and advice. Seventeen respondents employ co-ethnic and nineteen employ natives. The results indicate that most of the respondents use business networks to obtain resources. However, none of the respondents is a member of a chamber of commerce. All of them belong to ethnic associations. The use of social network to provide obtain financial resources is limited to ethnic business owners. Most of the businesses use employees that are family members and co-ethnics indicating strong ties. Finance and supplies are obtained from commercial banks and suppliers indicating weak ties. No respondent has ties with government agencies that support small businesses such as the Small Enterprise Development Agency and the Small Enterprise Finance Agency. This indicates a very weak level of official networks.

\begin{abstract}
Participant: "Nowadays I do not need financial help from my friends and relatives as my business has been in operation for eight years. I employ one person from my country and another local person. I also have suppliers who supply goods on credit because of our long relationship. I also have obtained an overdraft from my bank and also use my credit card for transactions. I also use an accountant to help me with my accounts. I am aware of government agencies that help small business but have never used any but I recently attended a small business course organised by a university"
\end{abstract}

Participant: "My business has grown very well in the last six years and I employ three people: two locals and my brother is also assisting me. I originally obtained a loan from my friend when I started my business. Nowadays, I have suppliers that supply goods to me at times on credit. I am aware of government agencies but have not used any of them. I do not belong to a chamber of commerce but I am a member of our trade association"

The results are consistent with the finding of similar empirical studies such as Sequeira and Rasheed (2006) and el Bouk et al. (2013) that entrepreneurs build networks that systematically vary by the phase of entrepreneurship. Sequeira and Rasheed (2006) point out that immigrant entrepreneurs acquire resources from two major sources: families and social network in their ethnic enclave. Family and friends provide convenient and low cost source of support. el Bouk et al (2013) find that strong ties especially family and friends who are already active as entrepreneurs are an important source of resources in the start-up phase of the business. These strong ties provide entrepreneurs with resources such as business information, financial support and access to business network. Business networks established during previous entrepreneurial activities also help to provide resources in the start-up phase. The results are inconsistent with Tesfom (2006) which finds that immigrant entrepreneurs themselves are the source of business idea and opportunity. Competition among entrepreneurs is the primary reason for withholding information and resources by co-ethnics. Therefore, first generation East African entrepreneurs in the United States of America often cross ethnic lines and ask entrepreneurs from other countries for business information.

\section{Conclusions}

Entrepreneurs' networks serve as a principal means of identifying and acquiring needed resources. However, different stages of venture development may need different resource dependencies. The study examined the networking behaviour of immigrant entrepreneurs during the start-up and established phases of their business. Networking includes official, business (managerial) and social networking. Official networks consist of government and government agencies. Social networks include friends, family and relatives and business networks comprise of competitors, suppliers, banks and customers, chambers of commerce and accountants. The results indicate that social networks which can be categorised as strong ties are dominant during the start-up phase of business. Business networks which can be categorised as weak ties are dominant in the established stage of the business. However social network which can be categorised as weak ties also help to provide resources during established stage as most entrepreneurs at this stage use family members and co-ethnics as employees. This implies that both business networks and social networks are used at the established phase of business by immigrant entrepreneurs. The use of official networks to obtain resources by immigrant entrepreneurs is non-existent during the the start-up and established phases. 


\section{Recommendations}

Immigrant entrepreneurs seem not to use official network to obtain resources. There are many government agencies in South Africa that were formed to provide financial and non-financial resources to small businesses. There is the need for immigrant entrepreneurs to be proactive and ensure that they are aware and use these agencies. Also, these agencies should include immigrant entrepreneurs as part of their business models. Immigrant entrepreneurs should not limit their networking to co-ethnics. Joining chambers of commerce can help to improve the legitimacy of their business. The failure rate of small business is very high. One of the causes of failure is the lack of management skills. Business advisors can help to improve management skills and decision-making of immigrant entrepreneurs. Accountants and consultants can provide support to small business owners. Immigrant entrepreneurs should ensure that they network with accountants and consultants.

\section{References}

Aaltonen Satu, Akola Elisa (2014), Lack of trust-the main obstacle for immigrant entrepreneurship? Available: http://pyk2.aalto.fi/ncsb2012/Aaltonen.pdf (March 15, 2014)

Adizes I (1979). Organizational passages-diagnosing and treating lifecycle problems of organizations. Organ Dynamics, (Summer), 3-25.

Aguilar Luis (2013) The Important Role of Immigrants in Our Economy Available:http://laht.com/article.asp?Articleld=1103740\& Categoryld $=13303$ (May 2, 2014)

Bricki, Nouria, Green, Judith (2007). A Guide to Using Qualitative Research Methodology. ? Available http://msf.openrepository.com/msf/handle/10144/84230 (March 19, 2014)

Chen CN., Tzeng LC., Ou WM., Chiang K.T (2007).The relationship among social capital, entrepreneurial orientation, organizational resources and entrepreneurial performance for new ventures. Contemporary Management Research, 3(3): 213-232.

Chen Y, He Y (2011). The impact of strong ties on entrepreneurial intention: An empirical study based on the mediating role of selfefficacy. Journal of Chinese Entrepreneurship, 3(2):147-158

Churchill N.C., Lewis, V.L (1983). The five stages of small business growth. Harvard Business Review, (May-June), 30- 51

Dalhammar Tobias (2004). Voices of Entrepreneurship and Small Business- Immigrant enterprises in Kista. ? Available. http://www.divaportal.org/smash/get/diva2:7559/FULLTEXT01.pdf (March 19, 2014)

Dana, LP (2007). Handbook of Research on Ethnic Minority Entrepreneurship: A Co- evolutionary View on Resource Management. Cheltenham: Edward Elgar Publishing

Drucker PF (1985). Innovation and Entrepreneurship, London: Pan Books Ltd.

Eisingerich, AB., Bell S.J (2008). Managing networks of interorganisational linkages and sustainable firm performance in business-tobusiness service contexts. Journal of Services Marketing, 22(7): 494 - 504.

El Bouk, F., Vedder, P., te Poel, Y (2013). The networking behavior of Moroccan and Turkish immigrant entrepreneurs in two Dutch neighbourhoods: The role of ethnic density. Ethnicities, 13(6) 771-794

Fairlie, RW., Lofstrom, M (2013). Immigration and Entrepreneurship Available.http://people.ucsc.edu/ rfairlie/papers/ (May 2, 2014)

Foss, L (2010). Research on entrepreneur networks: the case for a constructionist feminist theory perspective. International Journal of Gender \& Entrepreneurship, 2(1): 83-102

Gedeon, S (2010). What is Entrepreneurship? Entrepreneurship Practice Review, 1(3):16-35

Greiner LE (1972). Evolution and revolution as organisations grow. Harvard Business Review, 50(4): 37-46.

Grunhagen M, Mittelstaedt C (2002). Is bigger better? The anticipation of scale efficiencies and decision participation as motivation for aspiring multi-unit franchisees. International Journal of Entrepreneurial Behaviour \& Research, 8(3): 188-200.

Guion L, Diehl D, McDonald D (2014). Conducting an In-depth Interview. Available https://edis.ifas.ufl.edu/pdffiles/FY/FY39300.pdf (April 9, 2014)

Islam S (2009). Start-up and growth constraints on small-scale trading in Bangladesh. Journal of Chinese Entrepreneurship, 1(3): 227 239

Kalitanyi V, Viser K (2010). African immigrants in South Africa: Job takers or job creators. South African Journal of Economics and Management Sciences, 13(4): 376-391

Maas G, Herrington M (2006). Global Entrepreneurship Monitor South African Report. Available http:// www.gemconsortium.org/ document.aspx?id756> (February 6, 2013)

Machirori T, Fatoki O (2013). The Impact of Networking on Access to Debt Finance and Performance of Small and Medium Enterprises in South Africa. Journal of Economics, 4(2): 97-104

McClelland DC (1961). The achieving society. Princeton, NJ: Van Nostrand

Ngoc TB, Le T, Nguyen TB (2009). The impact of networking on bank financing: The case of small and medium enterprises in Vietnam. Entrepreneurship Theory and Practice, 33(4): 867-887.

Pfeffer J, Salancik GR (1978). The External Control of Organizations: A Resource Dependence Perspective. New York: Harper and Row.

Sequeira JM, Rasheed AA (2006). Start-up and growth of immigrant small businesses: the impact of social and human capital. Journal of Development Entrepreneurship, 11(4): 357-375. 
Stephens S (2013). Building an entrepreneurial network: the experiences of immigrant entrepreneurs. Journal of Enterprising Communities: People and Places in the Global Economy, 7(3): 233-244

Sullivan Diane (2006). Dynamic entrepreneurial networks: an investigation of entrepreneurs, new ventures and their networks. http://etd.fcla.edu/CF/CFE0001173/Sullivan_Diane_M_200608_PhD.pdf (Retrieved May 6 2014)

Tengeh R, Ballard H, Slabbert A (2012). Do immigrant-owned businesses grow financially? An empirical study of African immigrantowned businesses in Cape Town Metropolitan Area of South Africa. African Journal of Business Management, 6(19):6070-6081.

Tesfom G (2006). The role of Social Networks on the Entrepreneurial Drive of First East Africa origin Entrepreneurs in the Seattle Area. Journal of Asia Entrepreneurship \& Sustainability, 2(3).1-24

Thrikawala SS (201) .Impact of strategic networks for the success of SMEs in Sri Lanka. World Journal of Social Sciences, $1(2)$ : 108 119.

Vinogradov Evgueni (2008), Immigrant entrepreneurship in Norway. Available: http://brage.bibsys.no/xmlui/bitstream/handle /11250/140348/Vinogradov.pdf?sequence=1 (May 5, 2014)

Watson J (2007). Modelling the relationship between networking and firm performance. Journal of Business Venturing, 22: 852-874.

Zhang Q, Fung HG 2006. China's social capital and financial performance of private enterprises. J of Sma Bus and Ent Dev, 13(2): 198207. 